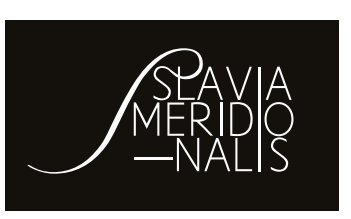

Citation:

Article No.: 2334

Bednarek-Bohdziewicz, A. (2020). Mickiewiczowska hermeneutyka „tego, co religijne”: Próba lektury postsekularnej. Slavia Meridionalis, 20, Article 2334. https://doi.org/10.11649/sm.2334

\title{
Agnieszka Bednarek-Bohdziewicz
}

Badaczka niezależna

http://orcid.org/0000-0002-8426-2483

\section{Mickiewiczowska hermeneutyka „tego, co religijne”. Próba lektury postsekularnej}

A żaden nie wprawuje łaty surowego sukna w wiotką szmatę... Ani leją wina młodego $\mathrm{w}$ stare statki ${ }^{1}$

\section{1.}

Podstawą rozważań na temat stosunku Adama Mickiewicza do oświeceniowego sekularyzmu oraz praktykowanej przez niego hermeneutyki „tego, co religijne" jest założenie, że romantyzm - jako epokę próbującą dyskutować z sekularną redukcją oświecenia - można odczytywać jako prąd, w którym ujawnia się przebłysk myślenia postsekularnego (zob. Iwanicki, 2014,

1 Słowa Ewangelii Marka według cytatu Adama Mickiewicza; Mickiewicz, 1955d, s. 451.

This work has been prepared at the author's own expense.

Competing interests: no competing interests have been declared.

Publisher: Institute of Slavic Studies, Polish Academy of Sciences.

This is an Open Access article distributed under the terms of the Creative Commons Attribution 3.0 PL License (creativecommons.org/licenses/by/3.0/pl/), which permits redistribution, commercial and non-commercial, provided that the article is properly cited. (c) The Author(s) 2020. 
ss. 11-49, 59; Kearney, 2011, s. 10 i n.; Warchala, 2007, 2013, 2014). Tak rozumiany postsekularyzm oznacza ponowne odkrywanie religii, szukanie inspiracji w religijnych pojęciach po rezygnacji z dogmatycznych pewników. Jego istotą jest postawa hermeneutyczna, którą Charles Taylor w rozmowie z Richardem Kearneyem nazywa aktem „ponownego uwierzenia” poprzez „powtórzenie do przodu” (repeating forward), „ofiarowanie przeszłości nowych perspektyw” (Kearney \& Taylor, 2016). Sam Kearney nazywa tę postawę (a w zasadzie proces) za pomocą neologizmu „anateizm” (Kearney, 2011), wskazując, że należy „ponownie” (ana-) odkryć wiarę, odświeżyć perspektywę sacrum. Nie chodzi o prosty powrót do tego, co było (konserwatyzm), lecz o przemyślenie tego, co było na nowo - w zmienionych warunkach po pracującej w kulturze sile sekularyzacji - i poprowadzenie refleksji dalej, poza zdogmatyzowaną religię instytucjonalną oraz poza zdoktrynowany racjonalizm likwidujący wszelki namysł dotyczący doświadczenia sacrum. Próba takiego czytania twórczości polskiego romantyka jest zgodna z proponowaną przez Agatę Bielik-Robson ogólną interpretacją romantyczności jako formuły „nowoczesnej tożsamości, której przyświeca nie tyle wizja powrotu do czasów przednowożytnych - a więc jak to chętnie ujmuje tradycja oświeceniowa, wizja negacji przemian modernizacyjnych - co odmienna wizja tego, co znaczy być człowiekiem nowoczesnym" (Bielik-Robson, 2004, s. 50).

Refleksja religijna jest swoistym metrum twórczości poetyckiej, publicystycznej i politycznej Mickiewicza ${ }^{2}$. Dość wspomnieć jego religijną lirykę i interpretację mistyki śląskiej, ujętą w epigramaty Zdań i uwag, czy koncepcje religijne wyłożone w prelekcjach paryskich w horyzoncie filozofii i polityki. $\mathrm{Na}$ marginesie zostawiam kontekst towianistyczny, którym przesiąknięte są III i IV kurs wykładów z Collège de France, by spróbować odczytać z nich wyabstrahowaną, ogólną myśl o potrzebie zachowania perspektywy religijnej oraz konieczności ponownego przemyślenia kategorii i pojęć teologicznych. Poeta eksploruje rozmaite rodzaje doświadczenia sacrum; jego rozumienie „tego, co religijne” można określić za Davidem Martinem jako „akceptację pewnego poziomu rzeczywistości pozostającego poza światem obserwowalnym, dostępnym nauce. Przypisuje się mu znaczenia oraz cele, które dopełniają (completing) i przekraczają (transcending) znaczenia oraz cele o wymiarze

${ }^{2}$ W odnalezionym przez Krzysztofa Rutkowskiego liście do matki Juliusz Słowacki krytycznie komentuje monotematyczność rodaka: „Mickiewicz bardzo już ostygł w poezji. W rozmowach ciągle religią na plac wyprowadza [...]” (Rutkowski, 2011). 
czysto ludzkim" (Martin, 1978/1993, s. 12, cyt. za: Puczydłowski, 2017, s. 15). Do dyskusji z sekularyzmem oświeceniowym Mickiewicz włącza więc poetycką prezentację ludowej cudowności i fantastyki, mysterium odczuwane w naturze oraz zawartą w prelekcjach paryskich analizę mitycznej interpretacji objawienia. Ostatecznie proponuje reinterpretację chrześcijaństwa: odczytanie nauk Jezusa z Nazaretu przekraczające skostniałą wykładnię urzędowego Kościoła, bliższe mistyce i żywemu doświadczaniu sacrum obecnemu w różnych tradycjach religijnych.

\section{2.}

Oświecenie w swoim projekcie modernitas gwałtownie zrywa z przeszłością: $z$ dotychczasowym społecznym układem, ale i z interpretacją dziejów, naruszając w ten sposób poczucie ciągłości doświadczenia historycznego. Wiek XVIII i wiek XIX to czas dwóch wielkich rewolucji (rewolucja francuska i rewolucja przemysłowa), przynoszących pragmatyczno-mechanicystyczny stosunek do świata, poczucie antropologicznej mocy i samowystarczalności oraz przekonanie, że najważniejsze moralne zdolności człowieka mogą istnieć bez odwołania się do istniejącej zewnętrznie (nadprzyrodzonej) podstawy (zob. Taylor, 2007, s. 245; por. Calasso, 2019, ss. 19-28). To także okres wielopoziomowego kryzysu: przesilenia historycznego, społecznego, kulturowego i moralnego, które dotknęło europejską cywilizację. Ów kryzys - jak się wydaje - wynika z faktu, że nowoczesność rodzi się (zbyt) gwałtownie. Jest to rewolucja wyzwalająca i wyobcowująca zarazem, skutkująca zerwaniem więzi między jednostką, tradycją i naturą. Wszystko to wywołuje transformację powszechnej wrażliwości społecznej Zachodu. Rodzi się „epoka świecka”: epoka zmian w sposobie doświadczania wiary w Boga oraz zmian $\mathrm{w}$ rozumieniu religii i podejściu do niej (por. Tomaszewska \& Barnat, 2017), wzmacnianych konfliktami chrześcijańsko-chrześcijańskimi (między katolicyzmem a protestantyzmem) oraz ujawniającym się pluralizmem moralno-duchowym. To o tym doświadczeniu pisze się jako o rozpadzie wspólnego uniwersum, wykorzenieniu, wygnaniu z mitu czy odczarowaniu świata (Bielik-Robson, 2000; Gauchet, 2019; Warchala, 2019; Weber, 2004). Charles Taylor konkluduje: „To, co Weber określił jako «odczarowanie», rozkład naszego pojmowania kosmosu jako sensownego ładu, zniszczyło rzekomo duchowy horyzont, wewnątrz którego żyli niegdyś 
ludzie” (Taylor, 2001, s. 35). Ów „proces rozpadu sakralnych wymiarów człowieka i teleologicznego ładu" dostrzega Mickiewicz (Kuziak, 2009, s. 90), który mierzy się z podważeniem religii i postulowanej przez nią wizji świata. Całokształt czasów sobie współczesnych poeta odczytuje jako głęboki i silny kryzys, „rozprzężenie” i „koniec epoki, to, co Pismo święte nazywa końcem świata” (Mickiewicz, 1955d, s. 428), skutkujący „w duszach jednostek ogólną omdlałością, zwątpieniem, cierpieniem, powszechnym niepokojem" (Mickiewicz, 1955d, s. 428).

Główną wadą owego wieku była nadmierna płochość, z jaką chciano wszystko wyrozumować, wszystko wytłumaczyć. Istotnie, dla ludzi XVIII wieku nie było już tajemnic. Do każdego zjawiska przystępowano z systematem gotowym do jego wyjaśnienia (Mickiewicz, 1955c, s. 282)

- konstatuje Mickiewicz w wykładzie XXII kursu II prelekcji paryskich. Z katedry Collège de France diagnozuje postępujące procesy racjonalizacji i sekularyzacji, które wiąże z rozwojem filozofii oświeceniowej oraz klasycznego idealizmu niemieckiego. W wykładach omawia historię filozofii nowożytnej i śledzi jej przebieg - od Kartezjusza, Spinozy, przez Leibniza i Locke’a do Kanta; analizuje myśl m.in. Fichtego, Schellinga i Hegla, zwłaszcza ostatniemu wytykając redukcyjny charakter proponowanej filozofii - ubóstwienie myśli ludzkiej i „rozumowych formułek” (zob. Mickiewicz, 1955d, ss. 134-135, 157):

Duch ludzki jest tedy jedynym Bogiem, jaki istnieje. [...] a jego istnienie objawia się w sposób najgłębszy w myśli. [...] Oto klucz całej filozofii i ostateczny wynik myśli europejskiej. Najwspanialszym objawieniem się ludzkości jest myśl. Nie masz nic świętszego, nic bardziej boskiego, nic większego ponad myśl (Mickiewicz, 1955d, s. 135).

Zwrot ku „abstrakcjom filozoficznym” to zdaniem paryskiego profesora konsekwencja braku wiary osłabionej uprzednio konfliktem religijnym chrześcijan (zob. Mickiewicz, 1955d, s. 138):

Filozofia ta rozwija się i zaczyna istnieć po traktacie westfalskim [1648 rok - przyp. $\mathrm{ABB}]$, kiedy wielkie życie religijne wszędzie ustaje. Do tego czasu chrześcijaństwo kroczyło było jak jeden człowiek (Mickiewicz, 1955d, s. 136).

Jednym ze źródeł sekularyzacji jest zatem według poety rozłam religii chrześcijańskiej. Od czasu reformacji i pod wpływem trzydziestoletniej wojny religijnej między protestanckimi państwami Świętego Cesarstwa Rzymskiego a katolicką dynastią Habsburgów "chrześcijaństwo staje w miejscu” (Mickiewicz, 1955d, s. 136): katolicyzm „kamienieje” a protestantyzm „butwieje” (Mickiewicz, 1955d, s. 136; gdzie indziej Mickiewicz dodaje, że także Cerkiew 
wschodnia jest „niema i obezwładniona”; Mickiewicz, 1955d, s. 355). Religia chrześcijańska grzęźnie coraz bardziej w dogmatycznym formalizmie i doktrynach teologów (zob. Mickiewicz, 1955d, ss. 265-266). Reakcją filozofów na krwawe wojny religijne, zawziętą walkę między teologami a postępującą martwotę ich wykładni, jest znużenie bądź wprost odwrócenie się od „zagadnień teologicznych"3 (Mickiewicz, 1955d, s. 137). Oto moment, w którym filozofia europejska zaczyna tłumaczyć wszystko bez interpretacji religijnej. Proponowanym przez nią sposobem poznania, zdaniem autora Dziadów, nie dociera się jednak do pełnej prawdy o człowieku i świecie, pomija bowiem najważniejsze kwestie: pytania o cel ludzkiej egzystencji oraz sens świata doczesnego, tj. „skąd przychodzimy i dokąd idziemy” (Mickiewicz, 1955d, s. 421). Zresztą, także „uczeni w Piśmie”, czyli funkcjonariusze Kościoła urzędowego, nie są zdolni rozwiązać tego „zagadnienia istotnego” (Mickiewicz, 1955d, s. 423). Kościół w swoim nauczaniu - zamiast porywać do czynu - "głosi doktrynę spokoju” (Mickiewicz, 1955d, s. 337). Cały „Zachód dusi się w swych doktrynach” (Mickiewicz, 1955d, s. 337) - diagnozuje ogólną kondycję Europy profesor Collège de France, dopowiadając w wykładzie VIII kursu IV, że:

I Kościół, i Nauka sprawiają jednakowo zawód. Kościół pozwala wyschnąć źródłu prawdziwego życia, Nauka zaś nader mało troszczy się o to, by wytrysło na nowo. Nauka roztrząsa wszelkie zagadnienia oprócz tego jednego, które dręczy każdego człowieka w stanowczych chwilach jego bytu i w epokach przemiany społecznej najwięcej obchodzi całe narody. [...] Uczeni poprzestali na powtarzaniu, że pod naszymi stopami istnieje ogień we wnętrzu ziemi, a ponad atmosferą krążą ciała niebieskie. Przy pomocy obliczeń zstępują w głąb kuli ziemskiej i wzbijają się aż do słońca. Ale cóż istotnego przynieśli dla rozwiązania zagadnienia szczęścia ludzkiego? (Mickiewicz, 1955d, ss. 420-421).

Krytykowanym przez Mickiewicza efektem postępującej sekularyzacji jest też racjonalizacja religii (w znaczeniu desakralizacji, zeświecczenia). Romantyk zauważa, że w dyskursie filozoficznym religia ograniczana jest do konserwatywnego systemu społecznego, okrajana do doraźnej polityki sprzyjającej układowi feudalnemu. Chrześcijaństwo, jego zdaniem, zostało zagarnięte

${ }^{3} \mathrm{~W}$ ten sposób Mickiewicz interpretuje też powstanie systematu Kartezjusza, który „znajduje odtąd jedyną ostoję w sobie samym. Wtedy to powiada sobie: Myślę, więc jestem; muszę starać się nakreślić sobie drogę na tym świecie” (Mickiewicz, 1955d, s. 137). Postawa myśliciela stanowi dla polskiego poety przykład „dążności ducha francuskiego”, którym jest „konieczność ustalenia sobie podstawy pewności moralnych” oraz „potrzeba poznania, w co powinien wierzyć w kwestii Boga i ludzkości”. To, jak się wydaje, jest dla Mickiewicza dowodem wyższości filozofii francuskiej nad niemiecką. 
(zamknięte w doktrynach) i upowszechnione w zniekształconej formie. Pod płaszczykiem tej religii demagodzy forsują swoje idee. Politykującym filozofom zarzuca hipokryzję: dostrzega „głęboką obłudę prawicy” i „nieudolność, powierzchowność, bezwład stronnictw centrum" (Mickiewicz, 1955d, s. 167). Konserwatyści sami nie wierzą w Boga ani nie przestrzegają zasad chrześcijaństwa („nie znam wśród filozofów ani jednego, który by miał całkowitą wiarę" - przekonuje Mickiewicz, 1955d, s. 166), ale chcą pewne dogmaty religijne zachować „dla ludu i usiłują ocalić jakieś strzępy chrystianizmu” (Mickiewicz, 1955d, s. 166). Ich strategią jest zachowanie pozorów, że podzielają zabobonne $\mathrm{w}$ ich mniemaniu wierzenia i praktyki obrzędowe wyznawców chrześcijaństwa, jednocześnie jednak gardzą wiarą ludu:

Trentowski i wielu innych filozofów nie bez przyczyny usiłują podszyć się pod płaszczyk chrześcijaństwa. To zwyczajna taktyka filozofów, którzy wyszli ze szkoły protestanckiej. Wynika ona z głębokiej pogardy, jaką żywią dla ludu. Lud, pospólstwo, to wszyscy ci, co się nie uczyli filozofii po uniwersytetach; lud w oczach tych filozofów nie powinien wiele wiedzieć; należy go pozostawić w ciemnocie i w przesądach należy nawet zachować pozory, że się podziela jego przesądy. I tak doktorowie protestanccy głoszą na kazalnicy prawdę, z której drwią w swoim gabinecie; mówią o tajemnicach chrześcijaństwa, które potem tłumaczą i wywracają formułkami rozumowymi. Podobnie postępują filozofowie (Mickiewicz, 1955d, ss. 159-160).

Za taką postawę paryski prelegent krytykuje też Schleiermachera, który: sam nie wierzy już nie tylko w autentyczność ewangelij, ale nawet nie wierzy w istnienie Jezusa Chrystusa; powiada, że kwestia historycznego istnienia Jezusa Chrystusa jest zbyteczna, nie ma najmniejszej wagi. Mimo to chciałby utrzymać święta religijne dla ludu i wykazuje filozoficznie ich użyteczność! (Mickiewicz, 1955d, s. 167).

W tym procesie niechlubną rolę pełni też Kościół instytucjonalny, który, $\mathrm{w}$ tym sensie desakralizuje religię, że ogranicza wiarę do powierzchownego ceremoniału. Religia nie ma już czego spodziewać się nawet po papieżu - utyskuje Mickiewicz. Według najwyższego katolickiego hierarchy ma ona bowiem polegać zaledwie na „zapewnieniu ludziom używania darów ziemi i swobody obchodzenia ceremonii religijnych" (Mickiewicz, 1955e, ss. 260-261). Kościół, zdaniem poety, „przestał stykać się z niebem” (Mickiewicz, 1955d, s. 503), stracił proroczego ducha i zaprzepaścił swoje duchowe posłannictwo. Co więcej: nie prowadzi wiernych ku wolności, nie zmienia świata rewolucyjnością chrześcijańskich zasad, lecz ze swą feudalną hierarchią cementuje zastany porządek społeczny i konserwuje układ poddańczy (zob. Mickiewicz, 1955d, ss. 414-415). Autor Dziadów krytykuje duchowieństwo za to, że „uznało ziemię za swą 
matkę" (Mickiewicz, 1955d, s. 413) i świetnie zaadaptowało się do świeckich/ światowych reguł. W kursie IV prelekcji Mickiewicz w wielu miejscach przekonuje, że Kościół - zamiast wyznaczać nowe ścieżki, popychać dzieje świata do przodu - nie nadąża za przyspieszonymi procesami modernizacyjnymi. „Nauka i piśmiennictwo kościelne nie mają już w swym urzędowym języku wyrazów na oddanie pojęć świata dzisiejszego", nie potrafią wyrazić aktualnych problemów, „nowych potrzeb lub popędów, nowych nadziei” (Mickiewicz, 1955d, s. 395). „Dawna teologia księża” przestaje zaspokajać duchowe i religijne potrzeby swoich wiernych (Mickiewicz, 1955d, s. 423), a „wyrażenia teologiczne” nie zawierają już „dość jasnego znaczenia” (Mickiewicz, 1955d, s. 421) - podsumowuje profesor.

Co zatem proponuje Mickiewicz? Nie idzie radykalnym tropem przywoływanego w prelekcjach skrajnego stronnictwa Brunona Bauera i Ludwiga Feuerbacha, którzy dostrzegając hipokryzję religijnego dyskursu heglistów, żądają, by otwarcie odrzucili wszystko, co jest związane z religią:

Powiedzcie otwarcie [...] że nie wierzycie ani w Boga, ani w nieśmiertelność duszy, że jesteście ateuszami, że trzeba już raz skończyć z Kościołem, z teologią, z tymi wszystkimi przestarzałymi pojęciami (Mickiewicz, 1955d, s. 167).

Poeta, choć ze zrozumieniem mówi o furii, z jaką wygłaszany jest powyższy pogląd, bo i sam zżyma się na religijną hipokryzję duchowieństwa i filozofów-racjonalistów, nie chce jednak rezygnować $\mathrm{z}$ religii w ogóle. Broni jej przed desakralizacją, którą uprawia urzędowy Kościół oraz sekularyzacją, którą szerzy filozofia oświeceniowa. Nie tylko zauważa potrzebę aktualizowania religijnych pojęć, przemyślenie i przeformułowanie ich tak, by odkrywały sens odczarowanego świata. Przede wszystkim kładzie nacisk na odzyskanie prawdziwego znaczenia religii, zrozumienie jej sensu w nowych czasach, odkrycie jej istoty i wartości.

\section{3.}

Pomysł polskiego romantyka na ratowanie „tego, co religijne” w namyśle o nowoczesnym świecie można nazwać postsekularną hermeneutyką (por. Ricoeur, 1985, s. 187 i n.). Proponuje on ożywienie wiary i religii poprzez powrót do źródeł - do wszystkiego, co było święte, prawdziwe i wielkie (Mickiewicz, 1955d, s. 477). By odnowić duchową kondycję świata trzeba przejść 
i przepracować w sobie wszystkie poziomy religijnych intuicji i dopełnić je swoją biografią. Należy rozwijać duchowość, traktując lata swojego życia, dawne wieki narodu i wcześniejsze epoki Kościoła jako szczeble ułatwiające dalsze wzrastanie (zob. Mickiewicz, 1955d, s. 474):

Doktorowie Kościoła orzekli, że każdy chrześcijanin powinien w ciągu życia przejść wszystkie epoki historii Kościoła, powinien tę historię skupić w sobie (Mickiewicz, 1955d, s. 474).

[...] trzeba uczuć się członkiem swego Kościoła, synem swego narodu, potomkiem odpowiedzialnym za wszystkich swoich przodków w rodzinie duchowej i doczesnej; trzeba być dziedzicem wszystkich przymiotów, wszystkich cnót, jakie naddziadowie nasi nabyli w pocie czoła i w krwawych ofiarach; trzeba całą przeszłość religijną i polityczną cisnąć w jedno ognisko, zamienić w jedną płonącą gwiazdę i ogień ten utrzymywać na ołtarzu swego ducha, aby cokolwiek w historii było świętego, prawdziwego i wielkiego, znalazło się w nas jako ziarno usiewne, jako żywotność, jako siła (Mickiewicz, 1955d, s. 477).

Istotą tego zwrotu do źródeł - czy to do mitów, folkloru, religijności ludowej, czy tradycji Kościoła i chrześcijaństwa pierwotnego - nie jest antymodernistyczne, konserwatywne tkwienie w przeszłości, lecz jej przepracowywanie ku lepszemu rozumieniu jej sensów w teraźniejszości. Poeta podejmuje - jak określa tę hermeneutyczną postawę Michał Kuziak - „wysiłek odzyskania znaczeń przeszłości, ich przekładu na język współczesności” (Kuziak, 2006, s. 83). Religia to dla Mickiewicza wiecznie aktualna rzeczywistość.

W liście z 9 września 1839 roku autor Zdań i uwag napomina Bronisława Trentowskiego, by w swoim namyśle filozoficznym nie lekceważył nie tylko myśli średniowiecznej, pism Ojców Kościoła i mistyków (Böhmego i Baadera) (Mickiewicz, 1955f, ss. 285-289), lecz także ludu - jego wrodzonej mądrości, z której podań, zdaniem poety, wszelka filozofia bierze źródło (Mickiewicz, 1955f, s. 286). Powtarza to przekonanie w prelekcjach, głosząc, że w podaniach i życiu ludów odnaleźć można pewne głębokie, warte zachowania intuicje (Mickiewicz, 1955d, s. 159). Racjonalistycznej filozofii oświeceniowej, zakleszczonej w piśmienności teologii oraz zrytualizowanej religijności Kościoła urzędowego, romantyk przeciwstawia zatem sensualną w swej prostocie religijność ludową - prostą, ale szczerą, pochodzącą z żywego doświadczenia sacrum. Wierzenia prostego ludu Mickiewicz wyraża w rejestrze kultury wysokiej, by - jak zauważa Bogusław Dopart - „przedłużyć promień gminnej wiary, dotrzeć do prawd wyższych i znaleźć dla nich odpowiedni wyraz” (Dopart, 1992, s. 67). Twórczość poetycka, na którą przekuwa odrzuconą przez racjonalizm oświe- 
ceniowy wiarę czy też intuicję ludu, służy mu jako pole do mediacji. Poprzez sztukę ukazuje duchowość człowieka prostego oraz włącza tę wrażliwość do dyskusji nad projektem nowoczesności (por. Bielik-Robson, 2004, s. 50).

Ludową mądrość, a nawet zabobon i płynącą z nich wizję świata poeta traktuje jako antidotum na despotyczne zapędy skrajnego racjonalizmu. W przywracaniu wyobrażeń, pojęć i znaczeń stłumionych przez oświeceniową filozofię, religię czy sztukę dostrzega możliwość przekroczenia racjonalnego porządku (zob. Dopart, 1992, s. 59). Z folkloru wydobywa m.in. fantastykę, która nie tylko poszerza wyobraźnię i skostniały w klasycyzmie język poetycki (por. Chmielowski, 1899, s. 34; Stefanowska, 2001, s. 11), łagodzi też „rozpadanie się wielu iluzji pod naciskiem nauki nowożytnej” - jak interpretuje ją Bielik-Robson. Zdaniem badaczki, inspirowana folkowym imaginarium fantazja romantyczna to „środek obronny psyche przed traumatyzującą obecnością wpływów mechanicznych" (Bielik-Robson, 2004, ss. 167-168). Fantastyka unieważnia twarde prawa racjonalizmu, a nawet kwestionuje oswojony porządek metafizyczny cudowności ${ }^{4}$. Wprowadza bowiem element irracjonalny - coś „nad rozum człowieczy" (Mickiewicz, 1955a, s. 36; zob. Kuziak, 2013, ss. 167-182) - wykraczający poza utarte dogmaty, „systemiki” i „formułki”. Przede wszystkim jednak fantastyka ludowych podań służy Mickiewiczowi za klucz do otwarcia wyobraźni i epistemologii na kategorię tajemnicy, którą z poznawczego horyzontu wyrugował dyskurs racjonalistyczny. To właśnie nieokreśloność tajemnicy napędza tryby myśli hermeneutycznej, której celem - jak zauważa Kuziak - „staje się ciągłe przekraczanie tego, co zostało osiągnięte i dążenie ku coraz to nowym wymiarom, odsyłanie do nieskończoności, do tego, co nieznane" (Kuziak, 2013, s. 171). Autorowi Ballad i romansów nie chodzi więc (a przynajmniej nie tylko) o budzący grozę ludowy spirytualizm i wywołującą tremendum siłę chaosmiczną natury, które rozdygocą emocje i w ten sposób zwrócą uwagę na metafizyczną stronę świata. Poprzez literackie przepisanie ludowych wierzeń Mickiewicz umożliwia pośrednie w nie wniknięcie, zrozumienie oraz odkrycie płynących z nich wartości: czucia i wiary, szacunku do

${ }^{4}$ Wyczerpujące rozróżnienie fantastyki i cudowności prezentuje M. Kuziak w rozdziale Ateny i Jerozolima: „[...] byty metafizyczne, które występują na gruncie fantastyki, dokonują destrukcji obowiązującego obrazu uniwersum, nie potwierdzają natomiast innego jego obrazu; dowodzą nieprzewidywalności kosmosu. Z kolei cudowność pozwala wykreować wizję uniwersum, w którym byty metafizyczne mają swoje miejsce, ich pojawienie się jest niejako czymś oczywistym (paradoksalnie, cudowność staje się zatem formą "racjonalizmu»)" (Kuziak, 2013, s. 170). 
tajemnicy, więzi łączącej wszystkie pokolenia i wszystkie stworzenia (zob. Stefanowska, 2001, ss. 31-33). Także w przedmowie do II części Dziadów romantyk tłumaczy swoją strategię wobec ludowych wierzeń. A jest nią wyczytywanie z praktyk pogańskich, przemieszanych z chrześcijaństwem ich istoty, czyli nauk i dążeń moralnych:

Cel tak poważny święta, miejsca samotne, czas nocny, obrzędy fantastyczne, przemawiały niegdyś silnie do mojej imaginacji; słuchałem bajek, powieści i pieśni o nieboszczykach powracających z prośbami lub przestrogami; a we wszystkich zmyśleniach poczwarnych można było dostrzec pewne dążenie moralne i pewne nauki, gminnym sposobem zmysłowie przedstawiane (Mickiewicz, 1955a, ss. 11-12).

Pierwotny poziom religijnej intuicji Mickiewicz dostrzega również w łączności prostego ludu z przyrodą, w „natchnieniu na widok wielkich zjawisk natury" (Mickiewicz, 1955d, s. 255):

W człowieku prostym, który nie rozbratał się jeszcze z przyrodą, a przy tym nie zerwał tajemnych nici wiążących go z Bóstwem, największym dziwem jest owo uczucie miłości, co tak dobrze pojmuje chwilę obecną i tak przenika przyszłość (Mickiewicz, 1955d, s. 499).

To właśnie z „wewnętrznego uniesienia odczuwanego na widok natury, z tej radości, jaką daje najgłębsze poczucie obecności Bóstwa” - jak referuje w prelekcjach profesor - bierze początek objawienie indyjskie (Mickiewicz, 1955d, s. 276), czy też wierzenia dawnych Słowian. Owo "głębsze i delikatniejsze odczucie życia przyrody" (Mickiewicz, 1955d, s. 290) poeta eksponuje w Sonetach krymskich. Natura jawi się jako emanacja sacrum i bodziec natchnienia, otwiera doświadczającego ją Pielgrzyma na tajemnicę.

Mickiewicz czerpie $z$ ludowych wierzeń i wrażliwości, ale jednocześnie wskazuje, że nie ich sensualna wykładnia metafizyki stanowi źródło odrodzenia religijnego, lecz postawa moralna oraz przeczucie boskości, które można z tych podań wyczytać. W zwyczajach i tradycji ludu odbija się religia pierwotna, żywe poczucie sacrum, które przetrwało dzięki temu, że nie zostało skażone, zagłuszone i zniekształcone w spekulacjach czy doktrynach naukowych i filozoficznych (Mickiewicz, 1955d, s. 255; zob. Kubik, 2012, s. 76). Zdaniem paryskiego wykładowcy lud przechował w pamięci i duchu także siłę duchową Kościoła pierwotnego.

W ślad za Creuzerem, Saint-Martinem, Goerresem i Kannem - Mickiewicz przygląda się tradycji ludowej i dawnym wierzeniom ujętym w mitologii z „wyższego punktu widzenia” (Mickiewicz, 1955d, s. 250), czyli bez pogardy i lekceważenia. Podobnie jak mądrość ludu jest dla romantyka świadectwem 
żywej - bo przekazywanej ustnie z pokolenia na pokolenie prawdy, także mit nie jest dla niego zaledwie wytworem fantastycznej wyobraźni ludów pierwotnych, lecz sposobem wyrażania pielęgnowanych w nim wspomnień z przeszłości (por. Ławski, 2010, ss. 73-121). W przeciwieństwie do szkół oświeceniowych deprecjonujących mity jako „zbiór baśni, powieści ludowych, zmyśleń poetów i mitografów" (Mickiewicz, 1955d, s. 248; por. Wiśniewska, 2010, s. 126), Mickiewicz - w myśl przywoływanego w prelekcjach Georga Friedricha Creuzera - próbuje „rzucić światło na najciekawszą stronę mitologii”, czyli „na ideę religijną” (Mickiewicz, 1955d, s. 248). Za niemieckim filologiem polski poeta podaje, że:

[...] mitologia jest panoramą mniemań i pojęć religijnych ludzkości; musi ona stanowić jedną organiczną całość, bo duch, który ją stworzył, jest jeden a w różnych podaniach rozpoznajemy ułamki pierwotnej religii (Mickiewicz, 1955d, s. 249).

Mitologia, pogaństwo czy religijność ludowa niosą w sobie odblask przeczuć głębokich boskich prawd: „Widzieliśmy tedy od samych początków społeczeństw ludzkich uczucie religijne, owo uniesienie, ów zachwyt, dający człowiekowi moc poznania Boga" (Mickiewicz, 1955d, s. 268). W rozmaitych odsłonach "tego, co religijne” poeta dostrzega tożsamą wszystkim tradycjom i wierzeniom intuicję sacrum i wzorem Saint-Martina stara się „sprowadzić je do wspólnego źródła” (Mickiewicz, 1955d, s. 249). Platformą łączącą, podsumowującą, tłumaczącą i rozwijającą, jego zdaniem, wszystkie „podania i mniemania” religijne jest chrześcijaństwo (zob. Szymański, 2017, s. 14). W Pierwszych wiekach historii Polski czytamy:

Chrześcijaństwo zaczęło rozwijać się w wiekach, które instynkt powszechny nazwał średnimi, i ze środka miało rzucić światło na początek i koniec świata, wytłumaczyć proroctwa i przepowiadać przyszłość. Kraina umysłowa pogaństwa była podobna do ówczesnej powierzchni ziemi: mniemania religijne błąkały się po niej tu i owdzie jak hordy koczownicze, podania i systemata filozoficzne, rozdzielone i sprzeczne z sobą, a potem osłabione i jednemu despotyzmowi, ateizmowi, jako cezarowi podległe. Wszystkie te podania i mniemania, wracając na łono wiary jako dzieci uwięzione albo zbiegłe z domu, zaczynały poznawać wspólnego Ojca i dom, i dawną okolicę, której nigdy całkiem nie zapomniały. Gałązka chrześcijańska znalazła pień dawnej tradycji, w którym łacno przyjąć się mogła, ale trzeba było wprzódy ściąć z tego pnia gałęzie i liście zdziczałe, to jest nałogi, zwyczaje i instytucje pogaństwa (Mickiewicz, 1955b, s. 42).

Z powrotem „na łono wiary” Mickiewicz wiąże nadzieję na odnowę gwałtownie zerwanej przez oświecenie więzi między jednostką a tradycją, naturą, wspólnotą i transcendencją. Romantyk krytykuje oświeceniowy pro- 
jekt indywiduacji podmiotu emancypujący człowieka z wszelkich zależności. Dyskutuje z przekonaniem o samowystarczalności, samostanowieniu i samosterowności człowieka; samodzielność nie musi oznaczać samoistności, a indywidualizm - solipsyzmu ${ }^{5}$. Słabość emancypacyjnej taktyki oświecenia tkwi, według poety, w pędzie do bezwzględnego wyzwolenia $\mathrm{z}$ „zadłużenia” wobec Boga, przodków, społeczności, ojczyzny, przyrody. Projekt ten wyzwala, ale i wyobcowuje. Zależności, od których chce się odciąć filozofia oświeceniowa, a które, jego zdaniem, umożliwiają istnienie i budują wspólnotę, Mickiewicz przedstawia w prelekcjach na (anty)przykładzie postawy Immanuela Kanta:

Kant, usadowiony dzięki swym niemieckim przodkom w kraju słowiańskim, który go żywił i swymi podatkami opłacał jego posadę, wychowany w szkole założonej ongi trudem biskupa katolickiego, nauczywszy się czytać na księgach zebranych staraniem protestanckich pastorów, pędzący spokojny żywot pod opieką króla pruskiego, który za niego wiódł wojnę, i dzięki żołnierzom, którzy bronili Królewca; Kant, który wszystko tedy zawdzięczał przeszłości, wyobraża sobie naraz, że nie wiedzieć skąd spadł na ziemię. Zadaje sobie pytanie, dlaczego istnieje, jak gdyby nie zaciągnął żadnych zobowiązań względem swej przeszłości, względem swego miasta, nie mówiąc już o Bogu; z tej fałszywej zasady wychodzi, aby wytłumaczyć Boga i świat stworzony (Mickiewicz, 1955d, ss. 138-139).

Więzi, o których mówi paryski profesor, są niczym naczynia połączone, usunięcie religijnego horyzontu, zerwane „spójni” z Bogiem, pociąga za sobą separację człowieka od innych ludzi, a w końcu i zerwanie łączności z całym stworzeniem. Racjonalistyczna interpretacja świata przez wyrugowanie pamięci o pierwotnej jedności ludzi i przyrody (zob. Schollenberger, 2010, s. 36), koronuje człowieka na władcę wszechświata, ugruntowując w nim pychę i skłonności despotyczne wobec innych, pożądanie władania wszystkim i wszystkimi:

Despotyczną władzę zaczyna człowiek zawsze wywierać najpierw na bliźnim, bo w codziennych stosunkach z bliźnim namiętności bądź też pycha podniecają go do okazywania bliźniemu swej przemocy. Niewolnictwo jest bardzo dawne na świecie; ale myśl o nieograniczonej władzy nad zwierzętami, drzewami, nad ziemią, nad całą naturą, ta myśl, że człowiek jest jej środkiem, bogiem, nieograniczonym despotą, to myśl czasów nowych, to ostatni wyraz pychy filozoficznej [...] (Mickiewicz, 1955d, s. 310).

Mickiewicz powątpiewa w ludzki prym i sugeruje, że „należałoby najpierw rozważyć, czy to prawda, że człowiek jest panem natury” (Mickiewicz, 1955d, s. 308).

${ }^{5}$ Należy nadmienić, że poeta nie odrzuca procesu indywiduacji, chce te ideały oświeceniowe zachować, nie rezygnując jednak $\mathrm{z}$ intuicji transcendencji. Indywiduacja miałaby przebiegać na zasadach bliższych chrześcijaństwu. 
Dyskutuje też z przyjętym stosunkiem wobec zwierząt, uznaje bowiem ich duchowość (zob. Schollenberger, 2010), którą wyczytuje z religijnych ksiąg (jako przykład wskazuje oślicę Balaama czy bydlęta przy betlejemskim żłobie, które „instynktem odgadują żywioł boski Zbawiciela jeszcze w dzieciątku”, zob. Mickiewicz, 1955d, s. 443). W prelekcjach przekonuje, że „świat czuje potrzebę wylewu nowego światła, które by mogło rozjaśnić nasze stosunki z Bogiem, z przyrodzeniem, które by pozwoliło nam uchwycić prawdziwiej i głębiej spójnię łączącą człowieka z Bogiem i z przyrodzeniem", czyli z całym światem stworzonym: innymi ludźmi, zwierzętami i roślinami (Mickiewicz, 1955d, ss. 322-323). Od odczuwania owej współzależności i „spójni” wiele zależy; poeta buduje wokół tego cały system etyczny, dotyczący kwestii społecznych, ekonomicznych i ekologicznych (Mickiewicz, 1955d, s. 323). Za wzór stawia zasady, którymi kierowały się ludy starożytne „nierównie bardziej moralne” w jego ocenie niż współczesna mu filozofia (zwłaszcza niemiecka): „Ich obrzędy religijne rozciągały opiekę nad niewolnikiem, zwierzęciem, nawet nad drzewem" (Mickiewicz, 1955d, ss. 308, 323).

Rozumowe formułki nie są w stanie pomóc pojąć, uzasadnić i uprawomocnić tych wszystkich powinowactw i więzi. Dopiero na nowo odczytane chrześcijaństwo, jak przekonuje Mickiewicz, „potrafi przywrócić i ułatwić nasze związki z wszechświatem, sięgając jedną ręką niebios, a drugą zagłębiając w tajniki natury ożywionej i natury nieorganicznej” (Mickiewicz, 1955d, s. 443). Co więcej, w przeciwieństwie do „rutynistów”, „pyszałkowatych uczonych” czy filozofów-doktrynerów, którzy bagatelizują instynktowne zasady ludu (zob. Mickiewicz, 1955d, ss. 308-323, 443) - religia ta rośnie na „pniu dawnej tradycji”, włącza i podsumowuje wszystkie wierzenia i intuicje, owo „uczucie religijne” przeszłych pokoleń; nie ignoruje ludowej mądrości zawartej w podaniach, lecz naświetla ich sens i rozwija uczucia moralne (zob. Mickiewicz, 1955d, s. 444). Jak każde nowe objawienie rozjaśnia „w nowy sposób nasze związki ze światem wyższym i ze światem niższym, z jestestwami niewidzialnymi i z jestestwami odzianymi w grubsze od naszego ciało" (Mickiewicz, 1955d, ss. 442-443). Chrystianizm zerwane więzi spaja przez miłosierne współodczuwanie - czyli, jak głosi w prelekcjach Mickiewicz, przez umiejętność „rozszerzania duszy”, rozbudzania w duchu takiej przenikliwości obejmującej wszystkie istnienia „jednakowym uczuciem” (Mickiewicz, 1955d, s. 443). Kierując się nim, religia ta doprowadziła, zdaniem profesora, do zniesienia niewolnictwa oraz zaprzestania rzezi na igrzyskach rzymskich, a także przyniosła „tkliwsze uczucia” i powinności względem zwierząt. Pozbawieni tej mocy filozofowie nie tylko nic nie zrobili w tych sprawach, lecz wręcz przyczyniali się do utrwalenia starego, 
krzywdzącego porządku (Mickiewicz, 1955d, s. 443). Istotę chrześcijańskiej metody poeta szczególnie podkreśla w Dziadach. W każdej części dramatu eksponuje wspólnotę, żywe współczucie oraz współodpowiedzialność.

\section{4.}

Mickiewicz w „tym, co religijne” dostrzega pierwotne źródło integrującej więzi i odpowiedzialności społecznej. Wiąże odrodzenie ducha religijnego z wynikającą z współodczuwania wielką zmianą społeczną, z rewolucją wolnościową (por. Bagłajewski, 2011, s. 175), w której mieści się emancypacja ludów, postulaty równouprawnienia kobiet ${ }^{6}$, sprzeciw wobec niewolnictwa, a także niemal braterska relacja wobec zwierząt. Paryski prelegent twierdzi, że już dawnych Słowian „prawda otrzymana od Boga” inspirowała „do stosowania i realizowania uczucia religijnego w swoim trybie życia”, do "rozwijania, udoskonalania życia domowego, życia rolniczego, życia społeczności, wiosek" (Mickiewicz, 1955d, s. 277). Szczególnie jednak potencjał rozwojowy - nadzieję na polepszenie systemu społecznego i prawdziwą przemianę świata - dostrzega w objawieniu chrześcijańskim (zob. Kuziak, 2013, s. 184). Wierzy, że transcendentna perspektywa dziejów ludzkości jest gwarantem zmian społecznych i potencjałem prawdziwej wolności i rozwoju:

Religia, dopóki ją odczuwano głęboko i potężnie jawiono, wzywała ludzi do tego, aby kroczyli naprzód i wstępowali wyżej. Kroczyć i wstępować wyżej to treść wszystkich nauk chrześcijaństwa (Mickiewicz, 1955d, s. 474).

Priorytetem dla poety staje się odnowienie, a w zasadzie gruntowna przebudowa Kościoła, który w aktualnej swojej wersji konserwuje ustrój feudalny i nie sposób budować na nim obywatelskiego świata. Mickiewiczowski Kościół przyszłości „to Kościół, który wyrazi i przyjmie do siebie ducha wolnościowego i w takim odnowieniu będzie w istocie powrotem do Kościoła pierwotnego" - streszcza pomysł poety Arkadiusz Bagłajewski (Bagłajewski, 2011, s. 178; por. Masłowski, 2006, ss. 175-191). Warto dodać, że byłby to powrót pogłębiony o doświadczenie rewolucji oświeceniowej - wzbogacony o jej wolnościowe postulaty, ale objaśnione chrześcijaństwem: jego poczuciem więzi i miłosiernym współodczuwaniem

${ }^{6}$ Ursula Phillips poglądy Mickiewicza dotyczące równouprawnienia kobiet nazywa feminizmem mesjanicznym, apokaliptycznym (zob. Phillips, 2009). 
z całym stworzeniem. Przejście przez wszystkie poziomy intuicji religijnej, aż do czasów współczesnych, jest tak istotne, ponieważ zadaniem chrześcijaństwa jest połączyć i wyjaśnić w sobie wszystkie tradycje i wszystkie filozofie. Opis upadku Kościoła rzymskiego zaczerpnięty z wizji Zygmunta Krasińskiego Mickiewicz przeformułowuje $\mathrm{w}$ wizję transformacji. Bazylikę przed runięciem ocali „nieprzeliczony zastęp ludzi szukających Kościoła przyszłości”:

Duchy narodów podtrzymają tę kopułę, zagrożoną runięciem. Przebiją w niej otwór dla światła niebieskiego, aby była podobna do owego panteonu, którego jest odtworzeniem, aby się znowu stała bazyliką całego świata, panteonem, pankosmosem, pandemonium, świątynią wszystkich duchów, aby dała nam klucz do wszystkich tradycji i wszystkich filozofii (Mickiewicz, 1955d, s. 364).

W szerokim kontekście strategię hermeneutyczną polskiego romantyka można odczytywać jako gest postsekularny. Z jednej strony poeta mierzy się z oświeceniowym odczarowaniem świata i coraz silniej obecną filozofią ateistyczną, $z$ drugiej towarzyszy mu poczucie zmierzchu religii instytucjonalnej wzmacniane pracującym w poecie wcześniejszym, bardzo silnym antyklerykalnym wolterianizmem (zob. Górski, 1925, ss. 9, 53-59, 61-62). Tak jak „systemiki” i „formułki” oświeceniowej filozofii, odrzuca też „stare bukłaki” religii - jej bezduszny ceremoniał oraz opresyjną, instytucjonalną skorupę (por. Warchala, 2013, s. 170, 2014, s. 74 i n.). Nie zgadza się ani na wyrugowanie transcendencji przez skrajny racjonalizm, ani konserwowanie jej w martwych teologicznych doktrynach. Poeta namawia do przemyślenia i uwewnętrznienia wszystkich poziomów religii, by poprowadzić ją dalej, nieustannie uaktualniając w swojej biografii ${ }^{7}$. $Z$ różnych, często zderzających się przekonań i wierzeń Mickiewicz destyluje prawdy uniwersalne i jako współczesny ich odbiorca - staje się ich tłumaczem i interpretatorem, mediatorem przeszłości z współczesnością.

W zaproponowanej optyce oświecenie jawi się jako przedwczesna nowoczesność, zaś mediujący rozmaite języki duchowości oraz łatający zerwane więzi romantyzm - jako jego dopełnienie będące specyficzną, postsekularną „autokorektą nowoczesności” (Warchala, 2014, s. 74)

7 Wzorem takiej postawy jest dla Mickiewicza Napoleon, który „nosił całą przeszłość chrześcijańską i realizował ją w swojej osobie”; Mickiewicz, 1955d, s. 392.

${ }^{8}$ Postawa Mickiewicza wpisuje się w rozumienie myśli postsekularnej, które proponuje Michał Warchala. Dla badacza postsekularyzm to „nie tyle kapitulacja nowoczesności wobec sił bardziej od niej pierwotnych, ile raczej przejaw wewnętrznej refleksyjnej pracy, swoistej autokorekty zachodniej modernitas, której celem jest ograniczenie niezamierzonych konsekwencji własnego rozwoju" (Warchala, 2014, s. 73). 


\section{BIBLIOGRAFIA}

Bagłajewski, A. (2011). Mickiewiczowska interpretacja Legendy Krasińskiego w prelekcjach paryskich. W M. Kalinowska, J. Ławski, \& M. Bizior-Dombrowska (Red.), Prelekcje paryskie Adama Mickiewicza wobec tradycji kultury polskiej i europejskiej (ss. 163-179). Wydawnictwa Uniwersytetu Warszawskiego.

Bielik-Robson, A. (2000). Inna nowoczesność: Pytania o współczesna formułę duchowości. Towarzystwo Autorów i Wydawców Prac Naukowych „Universitas”.

Bielik-Robson, A. (2004). Duch powierzchni: Rewizja romantyczna i filozofia. Towarzystwo Autorów i Wydawców Prac Naukowych „Universitas”.

Calasso, R. (2019). Nienazwana teraźniejszość (J. Ugniewska, Tłum.). Słowo/obraz terytoria.

Chmielowski, P. (1899). Filozoficzne poglądy Mickiewicza. Druk Józefa Sikorskiego.

Dopart, B. (1992). Mickiewiczowski romantyzm przedlistopadowy. Towarzystwo Autorów i Wydawców Prac Naukowych „Universitas”.

Gauchet, M. (2019). Apogeum i śmierć Boga: Chrześcijaństwo i rozwój Zachodu (M. Warchala, Tłum.). Kronos, 2019(2), 17-98.

Górski, K. (1925). Pogląd na świat młodego Mickiewicza (1815-1823). Kasa im. Mianowskiego.

Iwanicki, J. (2014). Procesy sekularyzacyjne a filozofia sekularna i postsekularna: Tradycja $i$ współczesność. Wydawnictwo Naukowe Wydziału Nauk Społecznych Uniwersytetu im. Adama Mickiewicza.

Kearney, R. (2011). Anatheism: Returning to God after God. Columbia University Press.

Kearney, R., \& Taylor, C. (2016, lipiec-sierpień). Wiara po śmierci Boga (rozmowa). Znak, 2016(734-735). http://www.miesiecznik.znak.com.pl/wiara-po-smierci-boga

Kubik, D. (2012). Mickiewiczowski projekt kultury słowiańskiej: Zarys problematyki dyskursu kulturoznawczego w prelekcjach paryskich. Zeszyty Naukowe Towarzystwa Doktorantów UJ: Nauki Humanistyczne, 2012(4), 61-82.

Kuziak, M. (2006). Wielka całość: Dyskursy kulturowe Mickiewicza. Wydawnictwo Naukowe Akademii Pomorskiej.

Kuziak, M. (2009). Mickiewicz wobec nowoczesności. W M. Kuziak (Red.), Romantyzm i nowoczesność (ss. 81-108). Towarzystwo Autorów i Wydawców Prac Naukowych „Universitas”.

Kuziak, M. (2013). Inny Mickiewicz. Słowo/obraz terytoria.

Ławski, J. (2010). Mickiewicz - mit - historia: Studia. Wydawnictwo Uniwersyteckie Trans Humana.

Martin, D. (1993). A general theory of secularization (Wyd. popr.). Gregg Revivals. (Oryginalna praca opublikowana 1978).

Masłowski, M. (2006). Synteza religijna Mickiewicza. W M. Masłowski, Problemy tożsamości: Szkice mickiewiczowskie i (post)romantyczne (ss. 175-191). Instytut Europy Środkowo-Wschodniej; Instytut Adama Mickiewicza.

Mickiewicz, A. (1955a). Dzieła: T. 3. Utwory dramatyczne (S. Pigoń, Oprac.). Spółdzielnia Wydawnicza Czytelnik.

Mickiewicz, A. (1955b). Dzieła: T. 7. Pisma proza (Cz. 3). Spółdzielnia Wydawnicza Czytelnik. 
Mickiewicz, A. (1955c). Dzieła: T. 10. Literatura słowiańska: Kurs drugi (L. Płoszewski, Tłum.). Spółdzielnia Wydawnicza Czytelnik.

Mickiewicz, A. (1955d). Dzieła: T. 11. Literatura słowiańska: Kurs trzeci i czwarty (L. Płoszewski, Tłum. \& Oprac.). Spółdzielnia Wydawnicza Czytelnik.

Mickiewicz, A. (1955e). Dzieła: T. 12. Trybuna Ludów (L. Płoszewski, Tłum.). Spółdzielnia Wydawnicza Czytelnik.

Mickiewicz, A. (1955f). Dzieła: T. 15. Listy (S. Pigoń, Oprac.; Cz. 2). Spółdzielnia Wydawnicza Czytelnik.

Phillips, U. (2009). Apocalyptic feminism: Adam Mickiewicz and Margaret Fuller. Slavonic and East European Review, 87, 1-38.

Puczydłowski, M. (2017). Religia i sekularyzm: Współczesny spór o sekularyzację. Towarzystwo Autorów i Wydawców Prac Naukowych „Universitas”.

Ricoeur, P. (1985). Egzystencja i hermeneutyka: rozprawy o metodzie (S. Cichowicz, Oprac.; E. Bieńkowska, Tłum.). Instytut Wydawniczy Pax.

Rutkowski, K. (2011). Snobizmy: Nieznany list Juliusza Słowackiego do matki. Dwutygodnik, 2011(68). dwutygodnik.com/artykul/2778-snobizmy-nieznany-list-juliusza-slowackiegodo-matki.html

Schollenberger, J. (2010). „Wejść między sforę” - projekt duchowości zwierząt: Mickiewicz Emerson. Wiek XIX: Rocznik Towarzystwa Literackiego im. Adama Mickiewicza, 3, 36-49.

Stefanowska, Z. (2001). Próba zdrowego rozumu: Studia o Mickiewiczu. Oficyna Wydawnicza RYTM.

Szymański, T. (2017). Les cours parisiens d'Adam Mickiewicz et l'idée de religion universelle. Slavia Meridionalis, 17, Artykuł 1339. https://doi.org/10.11649/sm.1339

Taylor, C. (2001). Źródła podmiotowości: Narodziny tożsamości nowoczesnej (M. Gruszczyński i in., Tłum.; T. Gadacz, Oprac. nauk.). Wydawnictwo Naukowe PWN.

Taylor, C. (2007). A secular age. Belknap Press of Harvard University Press. https://doi.org /10.2307/j.ctvxrpz54

Tomaszewska, A., \& Barnat, D. (Red.). (2017). Oświeceniowe źródła idei sekularyzmu. Wydawnictwo Uniwersytetu Jagiellońskiego.

Warchala, M. (2007). Religia romantyczna: Kilka głównych wątków. Kronos, 2007(1), 89-115.

Warchala, M. (2013). Religia romantyczna: Z genealogii myślenia postsekularnego. W A. Bielik-Robson \& M. A. Sosnowski (Red.), Deus otiosus: Nowoczesność w perspektywie postsekularnej (ss. 167-187). Wydawnictwo Krytyki Politycznej.

Warchala, M. (2014). Romantyzm i narodziny myśli postsekularnej. Logos i Ethos, 36(1), 73-85. https://doi.org/10.15633/lie.28

Warchala, M. (2019). Religia, polityka, odczarowanie: Marcel Gauchet w poszukiwaniu natury nowoczesności. Kronos, 2019(2), 5-16.

Weber, M. (2004). Racjonalność. Władza. Odczarowanie (M. Holon, Tłum.). Wydawnictwo Poznańskie.

Wiśniewska, L. (2010). Mity i paradygmaty w komparatystyce (między Mickiewiczem a dniem dzisiejszym. W L. Wiśniewska (Red.), Komparatystyka: Między Mickiewiczem a dniem dzisiejszym (ss. 91-132). Wydawnictwo Uniwersytetu Kazimierza Wielkiego. 


\section{Mickiewiczowska hermeneutyka „tego, co religijne”. Próba lektury postsekularnej}

Artykuł w syntetyczny sposób prezentuje ujawniającą się w twórczości Mickiewicza (zarówno poetyckiej, jak i wykładowej czy publicystycznej) postawę hermeneutyczną, która analizowana jest w horyzoncie myśli postsekularnej. Poeta dyskutuje z redukcyjnymi przejawami oświeceniowego sekularyzmu i jego świeckim humanizmem. Zachęca do zachowania „tego, co religijne” oraz do odnowienia religijnych pojęć. Nie chodzi jednak o prosty powrót do tego, co było (konserwatyzm), lecz o przemyślenie religii na nowo - w zmienionych warunkach po sekularyzacji. Mickiewicz śledzi rozproszone interpretacje śladów transcendencji czy tropów sacrum w rozmaitych tradycjach i sposobach mówienia o tym: od mitologii, folkloru, praktyk pogańskich, pobożności ludowej, po wyrafinowaną mistykę czy skomplikowaną teozofię. Romantyczny myśliciel jawi się jako dialogujący mediator między różnymi religijnymi językami, a także zderzającymi się przekonaniami i dyskursami (religijność zrytualizowana Kościoła urzędowego, racjonalistyczna filozofia oświeceniowa, sensualna w swej prostocie religijność ludowa). Celem tych działań jest odnowa zerwanej więzi („spójni”) łączącej człowieka z Bogiem i stworzeniem oraz odbudowa wspólnoty. W „tym, co religijne” szuka tego, co wspólne, wyłuskuje prawdy uniwersalne. Tym, co łączy i podsumowuje wszystkie okołoreligijne tradycje jest, jego zdaniem, chrześcijaństwo. Odrodzenie ducha religijnego poeta-polityk wiąże z rewolucją wolnościową (zniesienie niewolnictwa, równouprawnienie kobiet, emancypacja ludów). Wierzy, że transcendentna perspektywa dziejów ludzkości jest gwarantem zmian społecznych oraz źródłem prawdziwej wspólnoty. W szerokim kontekście strategię hermeneutyczną polskiego romantyka można odczytywać jako gest postsekularny, gdyż namawia do przemyślenia i uwewnętrznienia wszystkich poziomów religii, by poprowadzić ją dalej, nieustannie uaktualniając w swojej biografii.

Słowa kluczowe: Adam Mickiewicz, romantyzm, oświecenie, sekularyzm, postsekularyzm, religia, hermeneutyka, wspólnota

\section{Adam Mickiewicz's Hermeneutics of "the Religious": An Attempt at a Postsecular Reading}

This article synthetically presents the hermeneutic attitude revealed in Mickiewicz's work (poetry as well as lectures and journalism). It is analyzed from a post-secular perspective. The poet opposes the reductive secularism of the Enlightenment and its secular humanism. He also encourages preserving "the religious" and reviving religious concepts. However, this should not be a simple return to the past (conservatism), but rather a rethinking of religion with consideration to the new, secular conditions. Mickiewicz follows the scattered inter- 
pretations of the traces of transcendence or sacrum in various traditions and different ways of thinking: from mythology, pagan practices and folk piety to sophisticated mysticism and complicated theosophy. This Romantic thinker appears as a dialogue mediator between various religious languages, as well as between opposite beliefs and discourses (the ritualized religiosity of the official Church, rationalist Enlightenment philosophy, simple and sensual folk religiosity). The aim is to renew the broken relationship ('union') that connects man to God and creation, and to rebuild the community. In "the religious" he tries to find the common basis or extract the universal truths. In his opinion, Christianity is what connects and summarizes all religious traditions. According to this poet-politician, the revival of the religioncentered spirit is associated with the freedom revolution (the abolition of slavery, equality of women, emancipation of nations). He believes that the transcendent perspective of human history is the main guarantee of social change and true community. In a broader context, the hermeneutic strategy of this Polish Romantic can be interpreted as a post-secular stance, as it urges us to rethink and internalize all levels of religion, which should be continuously and constantly updated in one's life.

Keywords: Adam Mickiewicz, Romanticism, Enlightenment, secularism, postsecularism, religion, hermeneutics, community

\section{Notka o autorce}

Agnieszka Bednarek-Bohdziewicz (ag.bed@wp.pl) - doktor nauk humanistycznych, literaturoznawczyni, etnolożka i antropolożka kulturowa, badaczka terenowa, członkini Instytutu Kaszubskiego i Pomorskiego Towarzystwa Teologiczno-Filozoficznego. Autorka książki pt. Homo capax, capax hominis. Z problematyki antropologicznej w późnej twórczości Adama Mickiewicza (2019). Za tę publikację otrzymała Nagrodę Oddziału PAN w Gdańsku dla młodych naukowców za najlepszą pracę twórczą opublikowaną w 2019 roku. Zainteresowania badawcze: kultura symboliczna, antropologia religii, zwrot postsekularny, strategie kształtowania tożsamości kulturowej, dziedzictwo kulturowe, ikonosfera, antropologia literatury.

Agnieszka Bednarek-Bohdziewicz (ag.bed@wp.pl) - PhD in Literature, literary scholar, ethnologist and cultural anthropologist; field researcher, member of the Kashubian Institute and the Pomeranian Theological and Philosophical Society. Author of the book Homo capax, capax hominis. Z problematyki antropologicznej w późnej twórczości Adama Mickiewicza [Homo Capax, Capax 
hominis: On Anthropological Issues in Adam Mickiewicz's Late Works, 2019], which was granted the Gdańsk Branch of Polish Academy of Sciences award for early career scientists (best creative work published in 2019). Research interests: symbolic culture, anthropology of religion, post-secular turn, cultural identity formation strategies, cultural heritage, iconosphere, anthropology of literature. 